\title{
Dysfunction of the continent ileostomy: clinical features and bacteriology*
}

\author{
DARLENE G KELLY, S F PHILLIPS, K A KELLY, \\ W M WEINSTEIN, AND MARY J R GILCHRIST \\ From the Gastroenterology Unit and Department of Laboratory Medicine, Mayo Clinic and Mayo \\ Foundation, Rochester, Minnesota, and the Department of Medicine, University of California, Los Angeles, \\ California, USA
}

SUMmaRY The pathogenesis and treatment of dysfunction of the continent ileostomy was investigated in 12 patients, five of whom had asymptomatic malabsorption and seven of whom had acute complaints. The number of anaerobic bacteria in jejunal aspirates was increased in patients with pouch malfunction (range $10^{3}$ to $10^{8} / \mathrm{g}$ aspirate), but the microbiology of ileal effluent and the morphology of the ileal mucosa could not be correlated with dysfunction. Bile acid breath tests and lactose tolerance tests were not, however, reliable indicators of jejunal bacterial overgrowth. The symptoms, the malabsorption, and the number of jejunal and ileal anaerobic bacteria decreased in patients during treatment with metronidazole, implicating overgrowth of anaerobic bacterial flora in the pathogenesis of the syndrome.

The continent ileostomy (ileal pouch), devised by Kock, ' has been used as an alternative to conventional ileostomy for selected patients with ulcerative colitis and familial polyposis. ${ }^{2-5}$ The reservoir functions satisfactorily in most patients, but malfunction of the 'nipple valve' may occur in up to a third of patients and lead to incontinence. Improved surgical techniques appear, however, to have decreased the incidence of valvular dysfunction $;^{25}$ furthermore, better selection of patients should decrease the need for revision of prolapsed valves. ${ }^{6}$ Because Crohn's disease may recur after construction of a pouch, ${ }^{257}$ we believe that this diagnosis is a contraindication to the operation. ${ }^{25} 98$

More recently other syndromes of ileostomy dysfunction have been reported. These are described variably as: 'stagnant loop syndrome', 'enteritis', 'pouchitis', 10 and 'non-specific ileitis'. ${ }^{11}$ The corresponding clinical features may include diarrhoea, ${ }^{510-12}$ malabsorption of fat and

* Supported in part by grants from the National Foundation for Ileitis and Colitis. and the National Institutes of Health. Bethesda. Maryland (AM 6908. AM 206(15. AM 06342-(01. RR 585). A preliminary report of this work was presented at the American Gastroenterological Association annual meeting. May 1980.

Address for correspondence: Dr S F Phillips. Gastroenterology Unit. Mayo Clinic. Rochester. MN 559(15. USA.

Received for publication 20 August 1982 vitamin $\mathrm{B}_{12},{ }^{9}{ }^{12}$ proliferation of anaerobic bacteria in the pouch, ${ }^{9}$ inflammation in the pouch, ${ }^{11}$ incontinence, ${ }^{10} 11$ difficulty with intubation, ${ }^{11}$ and bloody discharge. ${ }^{5}$ We previously reported diarrhoea with some features of malabsorption in approximately one-third of asymptomatic patients with continent ileostomies. ${ }^{12}$ Here, we extend these studies to include patients with symptoms of ileostomy dysfunction; we also examined the possible mechanisms for dysfunction and the symptomatic response to metronidazole.

\section{Methods}

Patients With pouch Dysfunction (Table 1) These patients were selected on the basis of documented malabsorption and/or symptoms of a malfunctioning pouch. Five subjects (nos 1-5) with diarrhoea and malabsorption had been identified earlier. ${ }^{12}$ Their pouches were 'mature' (32-51 months postoperative, mean 40 months). On restudy, these five still had excess outputs of volume ( $>1000 \mathrm{~g} /$ day) and/or fat (Table 1). Seven patients (nos 6-12) had symptoms of dysfunction of the pouch (Table 1); these included bleeding from the pouch, diarrhoea, peristomal discomfort, minor leakage, and difficulties with intubation. In five, the onset of symptoms was during the first year after 
Table I Clinical features of patients with ileostomy dysfinction

\begin{tabular}{|c|c|c|c|c|c|c|c|c|}
\hline Patient & $\begin{array}{l}\text { Age } \\
\text { (yr) }\end{array}$ & Sex & $\begin{array}{l}\text { Afier } \\
\text { operation } \\
\text { (months) }\end{array}$ & $\begin{array}{l}\text { lleum } \\
\text { resected } \\
(\mathrm{cm})\end{array}$ & $\begin{array}{l}\text { Faecal } \\
\text { weight } \\
(g / 24 h)\end{array}$ & $\begin{array}{l}\text { Faecal fat } \\
(\% / 24 h)\end{array}$ & $\begin{array}{l}\text { Schilling tesț } \\
\text { nith intrinsic } \\
\text { factor } \\
\text { ( } \% \text { in urine) }\end{array}$ & Symptoms \\
\hline $1^{*}$ & 60 & $\mathbf{F}$ & 51 & 22 & 898 & 2.3 & 6 & Bone pain; otherwisc asymptomatic \\
\hline 2 & 39 & $\mathbf{F}$ & 35 & 14 & 1508 & 2) & 9 & Asymptomatic \\
\hline $3^{*}$ & 48 & M & 36 & 7() & 1785 & 10 & 12 & Asymptomatic \\
\hline 4 & 33 & M & 35 & 8 & 994 & 15 & 32 & Asymptomatic \\
\hline 5 & 72 & $\mathbf{M}$ & 50 & 6 & 763 & 11 & 6 & Asymptomatic \\
\hline 6 & 24 & $\mathbf{F}$ & 32 & 4 & $9(15$ & 5 & 18 & Blceding from pouch. RLO pain \\
\hline $7^{*}$ & 32 & $\mathbf{F}$ & 33 & $10-20$ & 1166 & 6 & 12 & Difficult intubation, pouch pain \\
\hline 8 & 18 & $\mathbf{F}$ & 1 & 8 & 1032 & 4 & 2 & Blecding from pouch. RLO pain \\
\hline $9^{*}$ & 19 & $\mathbf{F}$ & 9 & 5 & 1052 & $y$ & 12 & Nausca, diarrhoca. abdominal cramps \\
\hline 10 & 21 & $\mathbf{M}$ & 8 & 3 & 1485 & 11 & 26 & Difficult intubation. pouch pain. diarrhoca \\
\hline $11^{*}$ & 35 & $\mathbf{F}$ & 6 & $<10$ & 1332 & 5 & 24 & Blceding from pouch. cramps, diarrhoca \\
\hline
\end{tabular}

* Sccondary conversion of Brooke ilcostomy.

† Expressed as percentage dictary intake, approximate fat was $I(x) \mathrm{g} /$ day. Upper limit of normal. $7 \%$.

$\ddagger$ Normal $>9 \%$.

operation (range, one to nine months; mean, five months). Two were studied 32 and 33 months after operation.

\section{CONTROL PATIENTS (Table 2)}

In five patients (nos 13-17) with continent ileostomies, we had documented in a previous study $^{12}$ normal pouch effluents (weight $<1000 \mathrm{~g} / 24 \mathrm{~h}$. and faecal fat $<7 \mathrm{~g} / 24 \mathrm{~h}$ ), both of which were confirmed. These subjects had had their pouches for 35 to 63 months (mean, 50 months). A second control group (Table 2) consisted of eight patients (nos 18-25) who had conventional (Brooke) ileostomies constructed 20) to 58 months (mean, 38 months) previously.

All patients in the study had proctocolectomies performed for chronic ulcerative colitis. All gave written, informed consent for the protocol that had been approved by the Human Studies Committee of Mayo Clinic. The patients were hospitalised in the Clinical Research Center. They were given constant diets of known composition, designed to be similar to the usual dietary pattern at home, and including $100 \mathrm{~g}$ fat. None was taking medication. One patient (no. 4), who was taking salicylazosulphapyridine, discontinued the drug two weeks before the study.

Table 2 Clinical features of patients in control groups

\begin{tabular}{|c|c|c|c|c|c|c|c|}
\hline Patient & $\begin{array}{l}\text { Age } \\
\text { (yr) }\end{array}$ & Sex & $\begin{array}{l}\text { After operation } \\
\text { (months) }\end{array}$ & $\begin{array}{l}\text { lleum resected } \\
(\mathrm{cm})\end{array}$ & $\begin{array}{l}\text { Faecal weight } \\
(g / 24 h)\end{array}$ & $\begin{array}{l}\text { Fuecal fat* } \\
(\% / 24 h)\end{array}$ & $\begin{array}{l}\text { Schilling test } \\
\text { with intrinsic } \\
\text { factor } \\
(\% \text { in urine) }\end{array}$ \\
\hline \multicolumn{8}{|c|}{ Ileal pouch - normal function } \\
\hline 13 & 38 & $\mathbf{F}$ & 51 & 10 & 743 & 4 & 16 \\
\hline 14 & 27 & $\mathrm{~F}$ & 61 & 2 & 267 & 1 & 36 \\
\hline 15 & 28 & $\mathbf{F}$ & 63 & 0 & 546 & 4 & 16 \\
\hline 16 & 51 & $\mathbf{F}$ & 35 & 7 & 453 & 2 & 23 \\
\hline 17 & 43 & $\mathbf{F}$ & 40 & 4 & 543 & 3 & 17 \\
\hline \multicolumn{8}{|c|}{ Conventional ileostomy } \\
\hline 18 & 72 & $\mathbf{M}$ & 58 & 38 & 1073 & 5 & 24 \\
\hline 19 & 52 & $\mathbf{M}$ & 31 & 6 & 629 & 4 & 21 \\
\hline 20 & 20 & $\mathbf{M}$ & 30 & 17 & 613 & 2 & 27 \\
\hline 21 & 25 & $\mathbf{F}$ & 54 & 3 & 355 & 3 & 23 \\
\hline 22 & 50 & $\mathbf{M}$ & 20 & 8 & 603 & 2 & 16 \\
\hline 23 & 35 & $\mathbf{M}$ & 22 & 30 & 958 & 3 & 31 \\
\hline 24 & 49 & $\mathbf{M}$ & 36 & 5 & 719 & 2 & 17 \\
\hline 25 & 37 & $\mathbf{M}$ & 55 & 6 & 424 & 2 & 24 \\
\hline
\end{tabular}

* Expressed as percentage dietary intake excreted per day; approximate dietary fat was $100 \mathrm{~g} / \mathrm{day}$. Upper limit of normal. $7 \%$.

+ Normal $>9 \%$. 


\section{STUDIES OF II.EOSTOMY EFFIUENT}

Ileostomy effluent was collected for 48 hours, and the weight of the specimen was recorded. All specimens were frozen immediately upon collection and thawed only for homogenisation and preparation of aliquots, which were processed without delay. The fat content of effluents was determined by the method of van de Kamer ${ }^{1.3}$ and an output of $<7 \%$ of the daily fat intake was considered normal.

VITAMIN $B_{12}$ ABSORPTION TEST

Standard Schilling tests were performed by simultaneous ingestion of $0.25 \mu \mathrm{g}$ cyanocobalamin containing $0.8 \mu \mathrm{Ci}^{\text {si }} \mathrm{Co}$ cyanocobalamin and of $0.25 \mu \mathrm{g}$ cyanocobalamin containing $0.5 \mu \mathrm{Ci}{ }^{57} \mathrm{Co}$ cyanocobalamin bound to human gastric juice (Amersham Corporation Dicopac Kit). A loading dose of $1 \mathrm{mg}$ unlabelled vitamin $B_{12}$ was given intramuscularly $1 \frac{1}{2}$ to two hours after the oral dose. Urinary excretion of $>9 \% / 24 \mathrm{~h}$ of each isotope was taken as normal.

\section{JEJUNAL BIOPSIES}

Jejunal biopsies were obtained from the region of the ligament of Treitz with the Quinton Multipurpose Biopsy Tube. Biopsies were oriented, fixed in modified Bouin's fixative (1\% glacial acetic acid), and processed for light microscopy (haematoxylin and eosin) as previously described. ${ }^{1+}$ Jejunal histology was evaluated by one of us (WMW) without previous knowledge of the clinical features of the patients. Histological findings were categorised into normal jejunum. abnormal architecture (villous blunting), and the presence or absence of mucosal inflammation. Mucosal inflammation was defined as an unequivocal increase in lymphocytes and plasma cells ('round' cells) and/or the presence of polymorphonuclear leucocytes. Mucosal biopsy samples were also frozen for subsequent determination of mucosal sucrase and lactase activity. ${ }^{15}$

\section{MICROBIOLOGICAL ANALYSIS OF BOWEL}

CONTENTS

After an overnight (12 hour) fast, aspirates of proximal small intestinal content were obtained from the region of the ligament of Treitz, using a sterile tube. In addition, ileostomy effluent was collected from ileal pouches or appliances (Brooke ileostomies), approximately $1 \frac{1}{2}$ hours after the previous evacuation. Bowel contents were immediately transferred to $\mathrm{CO}_{2}$-filled vials for quantitative microbiological studies. Ten-fold dilutions through $10^{-8}$ were made using sterile Ringer's lactate as a diluent. For isolation of aerobic organisms, sheep blood agar, eosin methylene blue agar, and colistin-nalidixic acid agar plates were inoculated and incubated at $35^{\circ} \mathrm{C}$. For isolation of anaerobes, phenethylalcohol agar, rabbit blood agar with gentamicin and vancomycin, and laked sheep blood agar were inoculated and incubated in Gas Pak jars (Baltimore Biological Laboratories) containing catalyst and Gas Pak envelopes for the generation of hydrogen and carbon dioxide. After 48,72 , and 96 hours of incubation at $35^{\circ} \mathrm{C}$, colonies were picked to aerobic and anaerobic conditions so that strict anaerobes could.be differentiated and further identified to the genus or species level. Statistical comparisons of numbers of organisms were made between groups using the Wilcoxon's rank sum test for unpaired data.

The intestinal contents were examined for faecal pathogens by appropriate enrichment techniques. Campylobacter fetus ssp jejuni, Salmonella, and Shigella were sought specifically. Direct visual examination for presence of parasites was performed on each specimen. Faecal samples from nine of the patients with stomal dysfunction were examined for Clostridium difficile toxin (tests performed in the laboratory of Drs J W Chang and S L Gorbach).

\section{BREATH TESTS}

Bile acid breath tests were performed according to the method of Fromm and Hofmann. ${ }^{16}$ Patients were fasted for 12 hours before receiving an oral dose of $5 \mu \mathrm{Ci} 1-{ }^{14} \mathrm{C}$-cholyl glycine in $240 \mathrm{ml}$ Ensure (Ross Laboratories). Expired air was collected in hydroxide of hyamine before administration of the isotopes and then hourly for four hours after the bile acid was given. Trapped ${ }^{14} \mathrm{CO}_{2}$ was suspended in a Perma-fluor, Carbasoda (Packard Instruments) and quantified by counting against an external gamma standard in a Beckman LS 250 Scintillation Counter (Beckman Instruments).

Hydrogen breath tests were carried out after an oral dose of $50 \mathrm{~g}$ lactose in distilled water. ${ }^{15}$ in Expired air was collected for five minutes before and at hourly intervals for four hours after administration of lactose. Breath hydrogen was determined by gas chromatography. Simultaneous capillary blood samples were obtained before and at 15,30 , and 60 minutes after lactose. Glucose concentrations were measured using the hexokinase assay (Hexokinase Kit, Beckman Instruments).

ENDOSCOPY AND BIOPSY OF ILEOSTOMY

Ileal pouches and their valves were examined using a Fujinon model FG, QBF fibreoptic endoscope. Biopsies were obtained under direct vision at several separate sites with an ACMI 7035A biopsy forceps. The posterior wall of the pouch directly opposite the 
valve was avoided, as it is the region most likely to suffer trauma from the catheter used to empty the pouch. Tissue for histology was prepared as described for jejunal biopsies and was also evaluated by WMW.

\section{RESPONSE TO TREATMENT}

Patients with pouch dysfunction were treated with metronidazole $(250 \mathrm{mg}$ tid) and measurements of faecal weight, faecal fat, and the Schilling test with intrinsic factor were repeated at the end of a seven or 14 day course of the antimicrobial.

\section{Results}

Clinical features (Tables 1 and 2)

Patients 1-5 had laboratory features of malabsorption but were essentially asymptomatic. Even on specific questioning, only minor or no symptoms could be elicited. Except for one patient (no. 6), patients with symptoms (nos 6-12) had high faecal weights (>1000 g/24 h) and/or excessive faecal fat. All control patients (Table 2) had normal faecal weights and fat excretions except patient no. 18 who had an increased faecal weight. Four patients (nos 1, $5,8,12)$ had abnormal Schilling tests $(<9 \%$ ingested dose). All patients had normal serum vitamin $B_{12}$ levels. Other laboratory tests were normal or showed changes expected after proctocolectomy (mild systemic acidosis, mild hyperchloraemia). Two patients (nos 2 and 4) had abnormalities compatible with a diagnosis of liver disease associated with ulcerative colitis; these were longstanding and antedated proctocolectomy.

Jejunal histology was normal in all patients from whom tissue was available for interpretation, with one exception. Patient no. 2 had normal villous architecture but a mild increase of inflammatory (round) cells in the lamina propria and a single crypt abscess. Jejunal histology was not evaluated from three control patients (nos 17, 19,24) and two in the dysfunction group (nos 8 and 11).

MICROBIOLOGY OF JEJUNUM AND ILEAL EFFLUENT In jejunal aspirates the numbers of total bacteria, aerobic and anaerobic, were larger for the patients with dysfunction than for either of the control groups. Numbers of anaerobic bacteria are shown in Fig. 1; patients with pouch dysfunction differed from those with normally functioning continent $(p<0 \cdot 05)$, or conventional ileostomies $(p=0 \cdot 05)$. Counts of aerobic organisms reached $10^{5}-10^{9} / \mathrm{g}$ in subjects with malfunctioning ileostomies, $0-10^{4} / \mathrm{g}$ in patients with conventional ileostomies $(p<0.05)$, and $10^{2}-10^{7} / \mathrm{g}$ in controls with ileal pouches (NS). The major bacteria identified were of oral and

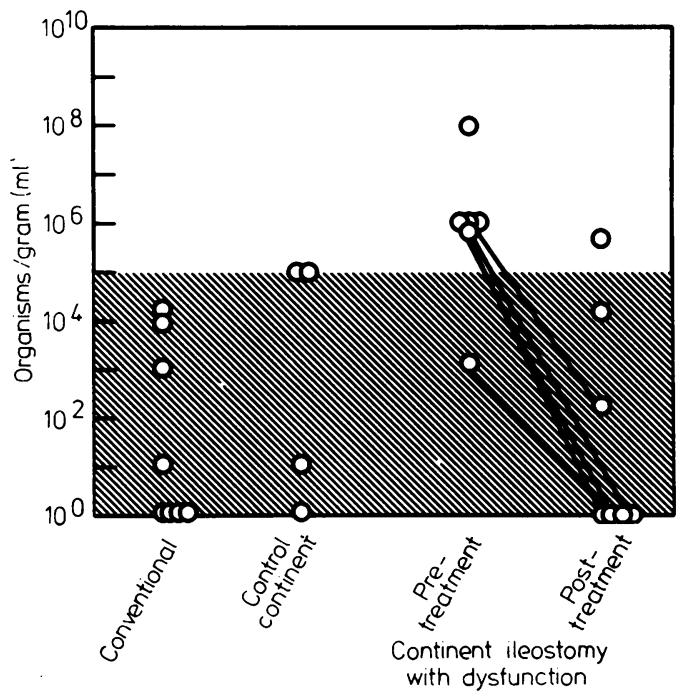

Fig. 1 Total anaerobic bacteria (Bacteroides, Clostridium. Peptostreptococcus, Fusobacterium, Veillonella, Propionic bacterium, Eubacterium) in jejunal aspirates from patients with conventional (Brooke) and continent (Kock) ileostomies. Control continent were asymptomatic without evidence of dysfunction, treatment given was metronidazole $250 \mathrm{mg}$ tid. Shaded area represents upper limit of normal in healthy subjects. Values are expressed as numbers of organisms per gram or millilitre of aspirate.

pharyngeal origin - that is, Streptococcus viridans, Bacteroides oralis, Veillonella parvula, Neisseria species - with a notable absence of characteristic 'faecal' flora. While aerobic bacteria are normally found in the proximal bowel in concentrations of $10^{2}-10^{4} / \mathrm{g},{ }^{18}$ the numbers of such organisms which were observed in patients with dysfunction $\left(10^{5}-10^{9} / \mathrm{g}\right)$ exceeded the numbers usually encountered in the upper small intestine.

On the other hand, no major differences were seen among groups when bacteria in the stomal effluents were quantified (Fig. 2). Flora in ileostomy effluent was primarily colonic in nature (Bacteroides fragilis, Escherichia coli, group D streptococci) in the three groups of patients with no apparent qualitative or quantitative differences being recognised among groups. Faecal bacterial pathogens, parasites, and Clostridium difficile cytotoxin were universally absent.

\section{BILE ACID BREATH TESTS (Fig. 3)}

Eight of the 12 patients with malfunctioning ileostomies had bile acid breath tests within normal limits ( $<50$ Fromm-Hofmann units) at two hours, and $10 / 12$ had normal levels $(<150$ FrommHofmann units) at four hours. Two patients (nos 1 


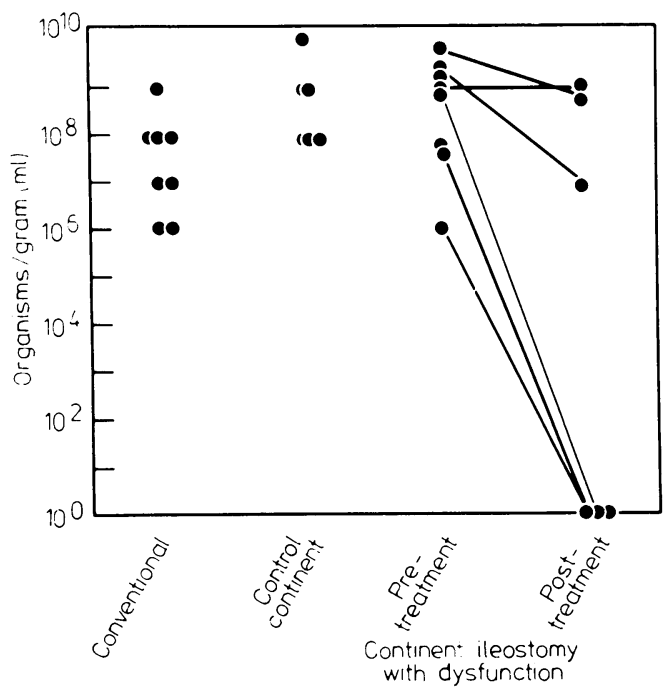

Fig. 2 Total anaerobic bacteria (Bacteroides, Clostridium, Peptostreptococcus, Fusobacterium, Veillonella, Propionic bacterium, Eubacterium) in stomal effluent from patients with conventional (Brooke) and continent (Kock) ileostomies. Control continent were asymptomatic without evidence of dysfunction, treatment given was metronidazole $250 \mathrm{mg}$ tid.

and 3) displayed clearly abnormal curves throughout the test. A common finding (10/12 patients). however, was a high level of ${ }^{14} \mathrm{C} \mathrm{O}_{2}$ in expired air at one hour, which in eight patient represented the peak value for the test. Control patients exhibited similar patterns with a peak value at one hour being observed in five patients (two with continent ileostomies and three with conventional ileostomies). In addition, two control patients with ileal pouches (nos 1.3 and 17) and two with conventional ileostomies (nos 18 and 19) had levels considered to be abnormal at either two or four hours.

TFSTS OF CARBOHYDRATE TOLERANCE

After a lactose load. excretion of hydrogen in the breath was normal (less than $(0.2 \mathrm{ml} / \mathrm{min}$ ) in the second hour in all patients. Lactose tolerance to the 5) g dose was abnormal in one patient in the dysfunction group (no. 7. peak rise of $12 \mathrm{mg} / \mathrm{dl}$ at 6) minutes) and borderline in another (no. 3, peak rise of $21 \mathrm{mg} / \mathrm{dl}$ at 15 minutes). All other patients had a normal peak rise $(>25 \mathrm{mg} / \mathrm{dl}) .{ }^{15}$ Lactase activity in jejunal biopsies was abnormal in the same two patients with dysfunction (nos 3 and 7) and in two controls (nos 16 and 18 ). The values were $(0 \cdot 3,0 \cdot 6$. (). 6 , and $(0 \cdot 1 \mathrm{U} / \mathrm{mg}$ wet weight respectively: all other levels were within the normal range (0.7-11.1 $\mathrm{U} / \mathrm{mg}) .^{15}$

\section{II.EAI. MORPHOLOGY (Table 3)}

Endoscopic appearances were normal in all control patients and in four patients with ileostomy dysfunction: these individuals (nos $1,2,3,5)$ had malabsorption, but no symptoms of dysfunction. Abnormal endoscopic findings included mild to moderate erythema. friability without discrete lesions (nos 8 and 10), and pinpoint erosions (nos 6 . 9,11 ). Correct postoperative anatomy of the "nipple valve was confirmed in all patients.

Tissue from the ileal pouch was adequate for interpretation in $11 / 12$ patients (17 biopsies) with pouch dysfunction. Seven patients had an abnormal architecture (characterised by villous blunting) and nine of 11 showed mild to moderate inflammatory changes. The inflammatory cells were predominantly round cells (plasma cells and lymphocytes), but polymorphonuclear leucocytes were often present as
Fig. 3 Bile acid breath tests for patients with continent ileostomies (-) and for those with conventional ileostomies (-.-.). Normal levels are demonstrated by the shaded areas (16). Most patients exhibited a peak ${ }^{14} \mathrm{CO}_{2}$ expiration at one hour regardless of clinical status.
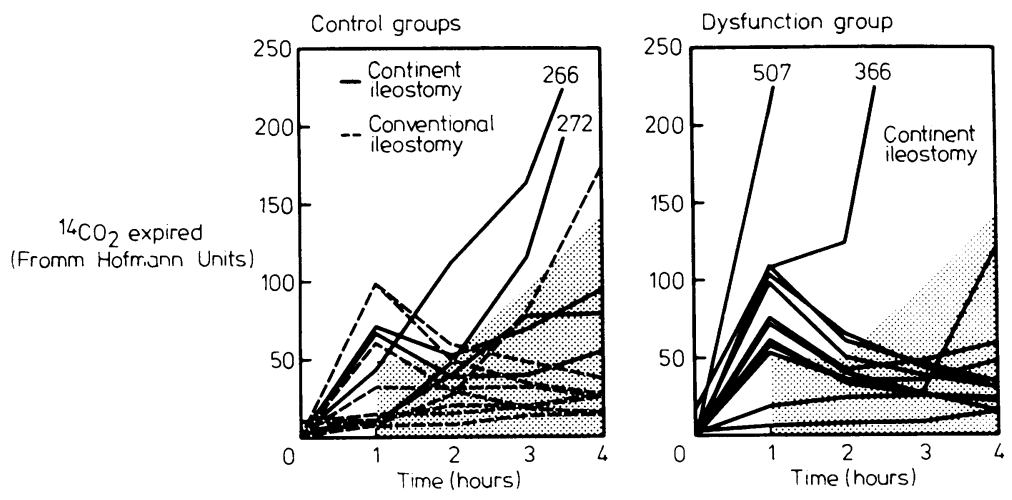


\begin{tabular}{|c|c|c|c|c|}
\hline & \multicolumn{3}{|c|}{ Histological findings } & \multirow{2}{*}{$\begin{array}{l}\text { Indescopic appearance } \\
\text { Normal }\end{array}$} \\
\hline & Vormal ileum & Villens blumting & $\begin{array}{l}\text { Inflammotors } \\
\text { changes }\end{array}$ & \\
\hline \multicolumn{5}{|l|}{ Ilecostomy dysfunction } \\
\hline Beforc antibiotic & $2 / 11$ & 711 & 911 & $4: 12$ \\
\hline After antibiotic & 28 & $5 \times$ & 6.8 & $x: 8$ \\
\hline Ileal pouch controls & $2 / 5$ & $2 / 5$ & 15 & 55 \\
\hline Conventional ilcostomy & $5 / 7$ & 27 & 27 & $8: 8$ \\
\hline
\end{tabular}

well (nos 1, 2, 5, 6, 8,9). Granulation tissue was prominent in two patients (nos 2 and 7). Crypt abscesses were identified in two (nos 6 and 9).

Ten biopsies were available from the five pouch controls' and tissue was obtained from seven conventional ileostomies. Four of the 12 controls had abnormal architecture and three of 12 showed inflammatory changes. In neither control group, however, was the frequency and severity of morphological features significantly different ( $\chi^{2}$ test) from biopsies obtained from patients with dysfunction. Moreover, histological change was certainly not a reliable indication of ileostomy dysfunction in any individual (Fig. 4). Normal tissue was obtained from malfunctioning ileostomies and, conversely, abnormal appearances were seen in controls. Furthermore, examination of serial sections revealed variability of morphological change within individual biopsies, emphasising the patchy nature of abnormalities.

RESPONSE TO TREATMENT (Table 4)

After metronidazole there was symptomatic improvement in all patients (nos 6-12) who presented with complaints of pouch dysfunction. In all instances there was relief of pain. cramps, or nausea, correction of the difficulty with intubation. and cessation of bleeding. All patients had a reduction in faecal weight, and, in addition, faecal fat decreased to normal or near normal values in patients 4, 5. and 10: three of the four patients with an abnormally low Schilling test returned to the normal range.

As expected, metronidazole decreased the number of anaerobic organisms in both jejunal and stomal specimens (Figs 1 and 2). Aerobic bacteria diminished in jejunal aspirates but increased in ileal effluent.

Eleven biopsies of pouch mucosa were obtained from eight patients after metronidazole. One patient (no. 1) whose pretreatment mucosal biopsy revealed inflammation had a normal biopsy after treatment. All others were unchanged by treatment.

FOLLOW-UP

Responses to a follow-up questionnaire indicated that four of 12 patients (nos 3, 4, 5, 8) had maintained a decreased ileal output without further

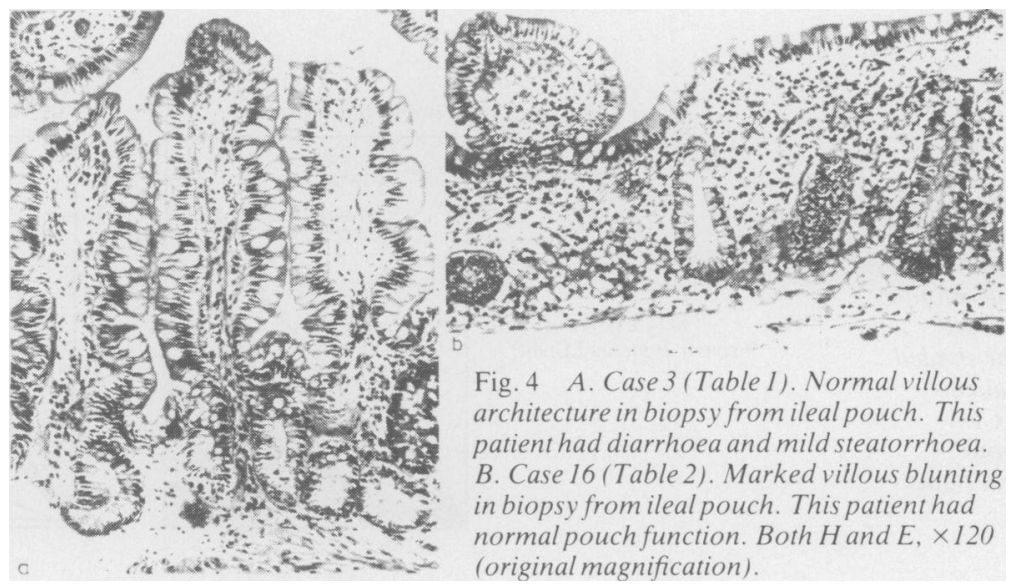


Tablet Absorptive function before and after

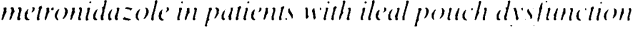

\begin{tabular}{|c|c|c|c|c|c|c|}
\hline \multirow[b]{2}{*}{ Paticht } & \multicolumn{2}{|c|}{$\begin{array}{l}\text { Fincul worghth } \\
(g-2+h)\end{array}$} & \multicolumn{2}{|c|}{$\begin{array}{l}\text { Fulecal tall', of } \\
\text { ingested farl }\end{array}$} & \multicolumn{2}{|c|}{$\begin{array}{l}\text { Sohilling test } \\
\text { with It } \\
I^{\prime} \text { in torinel }\end{array}$} \\
\hline & Before & After & Before & Afler & Before & ther \\
\hline 1 & s's & 675 & 23 & 21 & 6 & 13 \\
\hline 2 & 15 & 11117 & 20 & 43 & () & 10 \\
\hline 3 & 1755 & 1455 & 10 & 12 & 12 & 17 \\
\hline 4 & (9) 4 & $7+1$ & 15 & 9) & 32 & 18 \\
\hline 5 & 70.3 & $0+5$ & 11 & $s$ & () & 1) \\
\hline 6 & $9(15$ & +111 & 5 & 3 & IS & 311 \\
\hline 7 & 1106 & 904 & 6 & 3 & 12 & 12 \\
\hline$s$ & 11132 & 625 & 4 & 2 & 2 & 1.3 \\
\hline 111 & $1+5=$ & $1(10)$ & 11 & 6 & 26 & $\mathrm{NI}$ \\
\hline 11 & 1332 & 604 & 5 & ND & 24 & NI) \\
\hline 12 & Sin & $6+3$ & $s$ & s' & 3 & 4 \\
\hline
\end{tabular}

$N D=$ not donc

courses of antimicrobials. Eight have required additional treatment with various antibiotics, and two have also been treated with salicylazosulphapyridine. All control patients have continued to have no symptoms with their ileal pouches.

\section{Discussion}

Dysfunction of ileal pouches is due most often to partial or complete reduction of the nipple valve": valve prolapse leads to a characteristic svndrome of incontinence and difficult intubations." Although improvements in operative techniques and better selection of patients 5 " have lowered the incidence of valve failure. 5-10\% of patients will still develop this complication. Pouch dysfunction which is due to non-mechanical causes can. however, produce similar symptoms and it is important clinically to distinguish between these causes. Anatomical definition of the valve. by endoscopy and a barium 'pouchogram'. will usually suffice. Our patients with pouch dysfunction all had normal anatomy but were otherwise a mixed and unselected group. some with a spectrum of symptoms and others having asymptomatic diarrhoea and/or malabsorption.

We observed an impressive response to metronidazole in the patients with dysfunction of the continent ileostomy. In part this may be explained by the unexpected finding of bacterial overgrowth of the proximal small bowel. Even some patients with normal pouch function. however. had an apparent increase in jejunal flora. Thus, the presence of a stagnant reservoir within the pouch may predispose to bacterial overgrowth in the jejunum in all patients, and it is possible that a subtle qualitative difference in the flora determines whether mal- absorption or pouch dysfunction develops. The identities of the predominant organisms in our study did not reveal a specific micro-organism which could account for the difference. The response to metronidazole with its anaerobic spectrum of activity suggests that anaerobes or their byproducts might be responsible for the clinical effects. Patients who have required subsequent treatment, however, have responded to a variety of antibiotics. commonly ampicillin. Thus, an antibiotic with a broader spectrum might have been even more useful. Follow-up has indicated the necessity for repeated courses of antibiotics, a feature consistent with the diagnosis of "contaminated bowel syndrome".

Among other groups that have observed diarrhoea or dysfunction in patients with ileal pouches, ${ }^{5}$ 9-12 Schjønsby" and Loeschke ${ }^{19}$ implicated bacterial overgrowth in the pouch itself. Our bacterial counts in ileostomy effluent were not different among patients with pouch dysfunction. and those with normally functioning pouches or conventional ileostomies. The results reported here for conventional ileostomies are comparable with those of Gorbach et $a l^{20}$ and Finegold. ${ }^{21}$ Our bacterial counts from conventional and continent ileostomies are. however, one to two log units lower than those of Schjønsby." Thus, our findings do not suggest that quantitative microbiology of ileostomy effluent is of value diagnostically.

It should be noted that the jejunal flora was qualitatively that of the proximal gut, and did not reflect the content of the pouch. Factors responsible for jejunal bacterial overgrowth are uncertain, but reflux of pouch contents ${ }^{1}$ into the ileum (and beyond) seem unlikely. Altered motility of the proximal intestine, secondary to distension of the pouch, is suggested by the finding of slowed transit of a liquid meal. ${ }^{22}$ Reduced motility in the proximal small bowel might well impair clearance of oropharyngeal organisms from the jejunum.

In an attempt to identify other associations with bacterial overgrowth, we examined jejunal histology and disaccharidase activity and sought evidence of bile acid deconjugation. Bile acid breath tests were of limited benefit in predicting bacterial overgrowth of the proximal small intestine. Patients with both continent and conventional ileostomies, regardless of clinical status, had abnormal breath tests at the end of the first and second hours, suggesting rapid contact of bile acids with a flora capable of deconjugation. The test did not separate from controls the patients with increased numbers of bacteria in the proximal small bowel. The presence of faecal flora in the ileum would be expected to produce this pattern, making the application of 
traditional normal values obtained from healthy subjects of questionable validity. Only two of the 12 patients with pouch dysfunction had clearly abnormal bile acid breath tests throughout the four hour test.

The apparent discrepancy of the various indices of lactose absorption is, perhaps, not surprising in these patients who lack a colon. The failure of breath hydrogen excretion to increase may reflect the absence of a faecal flora able to metabolise unabsorbed lactose. This possibility is supported by the presence of flat lactose tolerance curves and decreased jejunal lactase activity in two patients who had normal hydrogen breath tests. Depletion of mucosal lactase and lactose intolerance are consistent with a diagnosis of bacterial overgrowth. ${ }^{2.3} .24$ but are not prerequisites. These biochemical abnormalities were infrequent and not associated with an abnormal morphology in our patients. Only one patient (no. 2) had a definite, but mild. non-specific histological lesion in the jejunum.

Many have reported a non-specific inflammation of the pouch mucosa associated with symptomatic malabsorption. ${ }^{5} 7101125$ We found a poor correlation between the endoscopic appearances of the pouch and the presence or absence of abnormalities on light microscopy. Thus, an abnormal endoscopic appearance of a pouch, though dramatic. may be of little significance. Mucosal histology was also of little help diagnostically; tissue was abnormal in some patients with well-functioning pouches and normal in some with dysfunction. In part, these findings may reflect patchy changes and the problems of obtaining representative samples. Our findings are in agreement with Nilsson and colleagues $^{26}$ who reported slight to moderate inflammatory reaction in the lamina propria of pouches in seven of 13 patients, even though histochemically the mucosa was normal.

There are several practical implications of the present study. When pouch function is disturbed, mechanical failure of the 'nipple valve' should be sought by endoscopy and barium studies. A positive diagnosis requires corrective re-operation. Endoscopy might also suggest an alternative aetiology and, although histology is not a reliable guide to inflammation in the pouch, biopsies should be obtained to look for recurrent Crohn's disease. Quantitative faecal outputs of fat and volume should be performed to document malabsorption if present. Faecal cultures and microscopy will be needed to exclude specific pathogens ${ }^{27}$ and/or toxins but we found that the identification of faecal ecology was unhelpful in contrast with the experience of others. ${ }^{9}$ 19 Empirical treatment of pouch dysfunction with antimicrobials may be reasonable. though efficacy should be monitored by repeating appropriate studies after treatment. If one antibiotic fails, another may succeed and some patients will require repeated courses of antibiotics. Given that a lifetime with an ileal pouch is to be expected, the occurrence of even borderline malabsorption cannot be ignored though the significance is still uncertain.

The authors are grateful to Anne Haddad. Jennifer Bouska, and Carol McLimans of the Mayo Clinic. Colleen Murdoch of the University of Alberta, and Esther Braden of UCLA for technical assistance. and to the staff of the Clinical Research Center. Mayo Clinic, for care of the subjects. Dr Sherwood Gorbach's laboratory performed assays for clostridial toxins. Mary Hanenberger provided expert secretarial help.

\section{References}

1 Kock NG. Intra-abdominal 'reservoir' in patients with permanent ileostomy. Arch Surg 1969: 99: 223-31.

2 Dozois RR. Kelly KA. Beart RW. Beahrs $O H$. Improved results with continent ileostomy. Ann Surg 1980): 192: 319-24.

3 King SA. Quality of life - the continent ileostomy. Ann Surg 1975: 182: 29-32.

4 Kock NG. Darle N. Kewenter J. Myrvold H. Philipson B. The quality of life after proctocolectomy and ileostomy: a study of patients with conventional ileostomies converted to continent ileostomies. Dis Colon Rectum 1974: 17: 287-92.

5 Kock NG. Darle N. Hulten L. Kewenter J. Myrvold H. Philipson B. Ileostomy Curr Prob Surg 1977: 14: 1-52.

6 Dozois RR. Kelly KA. Ilstrup D. Beart RW. Beahrs $\mathrm{OH}$. Factors influencing revision rate after continent ileostomy. Arch Surg 1981: 116: 610-3.

$7 \mathrm{King}$ SA. Enteritis and continent ileostomy. Conn Med 1977: 41: 477-9.

8 Myrvold HE. Kock NG. Continent ileostomy in patients with Crohn's disease. (Abstract.) Gastroenterology 1981; 80: 1237.

9 Schjønsby H. Halvorsen JF. Hofstad T, Hovdenak N. Stagnant loop syndrome in patients with continent ileostomy (intra-abdominal ileal reservoir). Gut 1977: 18: 795-9.

10 Gelernt IM. Continent ileostomy forum. Ostomy $Q$ 1979; 16: 56-9.

11 Halvorsen JF, Hermann P, Hoel R, Nygaard K. The continent reservoir ileostomy: review of a collective series of thirty-six patients from three surgical departments. Surgery 1978; 83: 252-8.

12 Kelly DG. Branon ME. Phillips SF. Kelly KA. Diarrhoea after continent ileostomy. Gut 1980): 21: $711-6$. 
13 Van der Kamer JH. ten Bokkel. Huinink H. Wevers HA. Rapid method for determination of fats in feces. $J$ Biol Chem 1949: 177: 347-5.5.

14 Perera DR. Weinstein WM. Ruhin CE. Small howel biopsy. Hum Pathol 1975: 6: 157-217.

15 Newcomer AD. McGill DB. Thomas PJ. Ilotmann AF. Prospective comparison of indirect methods for detecting lactase deficiency. $N$ Engl $J$. Med 1975: 29.3: 1232-6.

16 Fromm H. Hofmann AF. Breath test for altered bile-acid metabolism. Lancet 1971: 2: 621-5.

17 Levitt MD. Donaldson RM. Use of respiraters hydrogen $\left(\mathrm{H}_{2}\right)$ excretion to detect carbohydrate malabsorption. J Lah (lin Med 1970): 75: 937-45.

18 Donaldson RM Jr. The relation of enteric bacterial populations to gastrointestinal function and discase. In: Sleisinger MH. Fordtran JS. eds. Ciastrointestinal Disease, 2nd edn. Philadelphia: Saunders. 1978.

19 Loeschke K. Bolkert T. Kiefhaber P. Ruckdeschel G. Lohrs V. Bary S. Schaudig A. Bacterial overgrowth in ileal reservoirs (Kock pouch): extended functional studies. Hepato-(jastroenterol 1980): 27: 310-6.

20) Gorbach SL. Nahas L. Weinstein L. Studies of intestinal microflora. IV. The microflora of ileostomy effluent: a unique microbial ecology. (jastroenterology 1976: 53: 874-80.

21 Finegold SM. Sutter VL. Boyle JD. Shimada K. The normal florat of ileostoms and transwerse colostoms effluchts. I Inlect I)i 1970): 122: 376-81.

22 Kelly DK. Phillips SF. Kelly KA. Weinstcin WM. (iillchrist MIJR. Batcterial overerowth in the jejunum of pations with ileal pouches. (Abstract.) Gastro('merologe 19s(1): 78: 1193.

Z3 (iiannclla RA. Rout WR. Toskes PP. Jejunal brush border injury and impaired sugar and amino acid uplatic in blind loop syndrome. Gastroenterology 1974: 67: $96.7-74$

24 Bloch R. Menge H. Lorenz-Mever H. Stockert HG. Riecten EO. Functional. hiochemical and morphological alterations in the intestines of rats with experimental blind-loop syndrome. Res Exp Med 1975: 166: $67-78$.

25 Bonello JC. Thow GB. Manson RR. Mucosal enteritis: a complication of the continent ileostomy. Dis Colon Rectum 1981: 24: 37-41.

26 Nilsson LO. Kock NG. Lindgren I. Myrvold HG. Philipson BM. Ahren C. Morphological and histochemical changes in the mucosa of the continent ileostomy reservoir $6-10$ years after its construction. Scand J Gastroenterol 1980: 15: 737-47.

27 Drake AA. Huizenga KA. Van Scoy RE. Campylobacter fetus s.s. jejuni: a cause of diarrhea in a patient with a continent ileostomy. Dig Dis Sci 1982; 27: 1037-8. 